\title{
THE USE EFFECTS OF INTERACTIVE MULTIMEDIA EDUTAINMENT ON THE ACHIEVEMENT IMPROVEMENTS IN MATHEMATICS
}

\author{
Ade Saepudin, Saluky,Muhammad Ali Misri \\ saefuddin_ade@yahoo.co.id, saluky@syekhnurjati.ac.id, alimisri@gmail.com \\ Jurusan TadrisMatematika,Fakultas Ilmu Tarbiyah dan Keguruan \\ IAIN Syekh Nurjati Cirebon
}

\begin{abstract}
The aim of this study was 1) to determine the students 'response to the use of interactive multimedia-based edutainment 2) the improvement of students' mathematics achievement 3) to determine the effect of the use-based interactive multimedia edutainment to increase student mathematics achievement. This research is a quantitative method used was experimental research design pretest posttest control group. The population in this study were students of class VII MTs.KHAS Kempek Cirebon 2015-2016 school year. Sample class VII E as the control class VII and class $C$ as the experimental class. Data collection techniques in this study a questionnaire and tests. Based on the results of data processing, showed that students responded very well to the use of interactive multimedia-based edutainment. This is evidenced by the average percentage of each indicator by $84 \%$. Mathematics achievement test results of students in the experimental class to change the value of an average of 48,75 while in the control group experienced changes in the average value of 34,04. Based on the results of regression testing using SPSS 21.00 correlation coefficient $(r)=0,777$ which is included in the category of strong and coefficient of determination $\left(r^{2}\right)=0,603$, or $603 \%$. The regression equation is $Y=-114,714+1,561 X$. This equation has a coefficient of linear regression direction $(b)=1,561$ is positive, meaning that the response of students moved up one unit, then the student achievement in mathematics will increase 1,561 times. Statistical analysis showed that tcount $>$ table $=8,273>1,68$. This means there is significant influence based interactive multimedia edutainment use to increase student mathematics achievement. The magnitude of effect was $60,3 \%$ and the rest influenced by other factors.
\end{abstract}

Key Words: Based Interactive Multimedia Edutainment, Learning Achievement 


\section{PENDAHULUAN}

Dunia pendidikan merupakan dunia yang sangat penting dalam kehidupan manusia. Manusia yang selalu diiringi pendidikan, kehidupannya akan selalu berkembang ke arah yang lebih baik. Adanya perkembangan kehidupan, pendidikan pun mengalami dinamika yang semakin lama semakin berkembang dan berusaha beradaptasi dengan gerak perkembangan yang dinamis tersebut. Itulah sebabnya, pendidikan yang kini diterapkan kepada anak kita tidak sama dengan pendidikan kita sewaktu sekolah dulu. Setiap zaman, pasti akan selalu ada perubahan yang mengarah pada kemajuan pendidikan yang semakin baik. Adanya perubahan dalam proses pembelajaran dari yang konvensional kearah yang lebih modern yang lebih efektif dengan memanfaatkan teknologi dibidang pendidikan seperti alat-alat elektronik, film, CD pembelajaran dan sebagainya memberi arah tersendiri bagi kegiatan pendidikan.Tuntutan inilah yang membuat kebijakan untuk memanfaatkan media teknologi dalam pengelolaan pendidikan. Terlebih pemanfaatan media teknologi itu dalam pembelajaran matematika.

Pembelajaran matematika pada dasarnya bertujuan untuk membantu melatih pola pikir siswa agar dapat memecahkan masalah dengan kritis, logis, cermat dan tepat (Rohmawati, 2009). Anak didik yang terbiasa berpikir secara matematik akan lebih mudah berpikir logis dan rasional. Kemampuan berpikir semacam ini sangat dibutuhkan dalam menyongsong era modern yang menuntut kompetisi seperti sekarang ini. Matematika bukan hanya diperlukan sebagai alat penghitung yang pasif, akan tetapi terutama merupakan bahasa inti bagi perumusan semua teori yang melandasi semua bidang ilmu (Ningsih, 2014). Mengingat begitu pentingnya mata pelajaran matematika maka meningkatkan prestasi belajar matematika sangat perlu dilakukan.

Prestasi belajar dalam kamus besar bahasa Indonesia (Tim Penyusun Kamus, 1999) adalah penguasaan pengetahuan atau keterampilan yang dikembangkan oleh mata pelajaran, lazimnya ditunjukan dengan nilai tes atau angka yang diberikan oleh guru. Berdasarkan pentingnya fungsi prestasi belajar bagi siswa, maka keberhasilan belajar siswa perlu diperhatikan karena sangat menentukan prestasi belajar siswa.

Prestasi belajar siswa banyak dipengaruhi oleh berbagai faktor, baik berasal dari dalam diri siswa itu sendiri (internal) maupun dari luar (eksternal). Prestasi belajar yang dicapai oleh siswa pada hakikatnya merupakan hasil interaksi dari berbagai faktor tersebut. Oleh karena itu, pengenalan guru terhadap faktor yang mempengaruhi prestasi belajar siswa sangat penting artinya dalam rangka membantu siswa dalam mencapai prestasi belajar yang seoptimal mungkin sesuai dengan kemampuannya masing-masing.

Adapun faktor-faktor yang dimaksud adalah sebagai berikut(Setiawati, 1993:9-12):

1) Faktor yang berasal dari diri sendiri (Internal)

(a) Faktor jasmaniah (fisiologi), yang termasuk faktor ini adalah panca indera yang tidak berfungsi sebagaimana mestinya, seperti mengalami sakit, cacat tubuh atau perkembangan yang tidak sempurna, berfungsinya kelenjar tubuh yang membawa kelainan tingkah laku.

(b) Faktor psikologis terdiri atas:

i. Faktor intelektif yang meliputi faktor potensial yaitu kecerdasan dan bakat serta kecakapan nyata (prestasi yang dimiliki),

ii. Faktor nonintelektif, yaitu unsur-unsur kepribadian seperti sikap, kebiasaan, minat, kebutuhan, motivasi, emosi, dan penyesuaian diri,

iii. Faktor kematangan fisik maupun psikis.

2) Faktor yang berasal dari luar diri (Eksternal)

(a) Faktor sosial yang terdiri atas:

i. Lingkungan keluarga,

ii. Lingkungan sekolah,

iii. Lingkungan masyarakat, dan

iv. Lingkungan kelompok

(b) Faktor budaya, seperti adat istiadat, ilmu pengetahuan, teknologi, dan kesenian.

(c) Faktor lingkungan fisik, seperti fasilitas rumah dan fasilitas belajar.

Ditinjau dari fungsinya, fungsi prestasi belajar berfungsi sebagai berikut (Arifin, 1990:3-

4):

1) Prestasi belajar sebagai indikator kualitas dan kuantitas pengetahuan yang telah dikuasai anak didik. 
2) Prestasi belajar sebagai lambang pemuasan hasrat ingin tahu.

3) Prestasi belajar sebagai bahan informasi dalam inovasi pendidikan.

4) Prestasi belajar sebagai indikator intern dan ekstern dari suatu institusi pendidikan. Indikator intern adalah prestasi belajar dapat dijadikan indikator tingkat produktifitas suatu institusi pendidikan. Sedangkan indikator ekstern menunjukkan bahwa prestasi belajar dijadikan indikator kesuksesan anak didik di masyarakat.

5) Prestasi siswa dapat dijadikan indikator terhadap daya serap (kecerdasan) anak didik.

Di dunia pendidikan, teknologi khususnya multimedia mempunyai peranan yang sangat penting dalam proses pembelajaran salah satunya yaitu dapat mengatasi faktor yang menghambat proses belajar mengajar. Mayoritas masyarakat percaya bahwa multimedia dapat membawa pada pembelajaran yang aktif, menyenangkan dan efektif (Tanrere \& Side, 2012). Multimedia adalah sebuah program untuk penyampaian konten digital secara keseluruhan dengan menggunakan kombinasi terpadu antara teks, audio, gambar dua dimensi (2D), dan tiga dimensi (3D), video dan animasi (Munir, 2013). Teknologi multimedia dapat dimanfaatkan untuk menyusun materi pembelajaran di berbagai disiplin ilmu dalam kemasan yang interaktif, misalnya dalam format yang dikenal dengan edutainment. Edutainment berasal dari kata education dan entertainment. Education berarti pendidikan, sedangkan entertainment berarti hiburan. Jadi, dari segi bahasa, edutainment adalah pendidikan yang menghibur atau menyenangkan. Sementara itu, dari segi terminologi, edutainment adalah suatu proses pembelajaran yang didesain sedemikian rupa, sehingga muatan pendidikan dan hiburan bisa dikombinasikan secara harmonis untuk menciptakan pembelajaran yang menyenangkan. Dalam hal ini, pembelajaran yang menyenangkan biasanya dilakukan dengan humor, permainan (game), bermain peran (role play), dan demonstrasi(Hamid, 2014).

Penggunaan komputer sebagai media pembelajaran yang memuat aspek edutainment didukung oleh penggunaan berbagai elemen, yaitu: teks, grafik, audio, dan video. Adanya kombinasi dari berbagai elemen tersebut, unsur edukasi yang disampaikan dalam bentuk entertainment dapat membangkitkan keinginan belajar dan bahkan membawa pengaruhpengaruh psikologis terhadap siswa. Konsep edutainment tentu akan sangat menarik apabila dikembangkan dengan sistematis dan terstruktur. Jika berjalan dengan baik, tentu saja suasana pembelajaran di kelas akan berubah, dari sesuatu yang menakutkan menjadi sesuatu yang menyenangkan, dari sesuatu yang membosankan menjadi membahagiakan. Mereka ingin dan ingin terus belajar di kelas, karena dipenuhi rasa semangat dan antusiasme yang tinggi untuk mengikuti pelajaran.

Penggunaan multimedia interaktif yang berbasis edutainment dalam pembelajaran matematika ini diharapkan agar siswa dapat lebih memahami pelajaran matematika dan dapat meningkatkan prestasi belajar yang lebih optimal. Hal itulah yang melatar belakangi penulis mengadakan penelitian di MTs. KHAS Kempek Kabupaten Cirebon untuk mengetahui seberapa besar "Pengaruh Penggunaan Multimedia Interaktif Berbasis Edutainment terhadap Peningkatan Prestasi Belajar Matematika Siswa".

\section{KAJIAN PUSTAKA}

\section{a. Multimedia Interaktif Berbasis Edutainment}

Secara etimologi multimedia berasal dari kata "multi" (bahasa latin, nouns yang berarti banyak, bermacam-macam), dan "medium" (bahasa latin yang berarti sesuatu yang dipakai untuk menyampaikan atau membawa sesuatu). Kata medium dalam American Heritage Electronic Dictionary (1991) juga diartikan sebagai alat untuk mendistribusikan dan mempresentasikan informasi. Jadi, subyek multimedia adalah informasi yang bisa dipresentasikan kepada manusia. Secara sederhana presentasi informasi itu sering dikategorikan sebagai ilmu pengetahuan (Ariani, 2010).

Adapun secara terminologi multimedia adalah media yang menggabungkan dua unsur media atau lebih yang terdiri dari teks, grafis, gambar, foto, audio, video, dan animasi secara terintegrasi. Multimedia terbagi menjadi dua macam, yaitu: multimedia linier dan multimedia interaktif. Multimedia linier adalah suatu multimedia yang tidak dilengkapi dengan alat pengontrol apapun yang dapat dioperasikan oleh pengguna. Multimedia ini berjalan sekuensial (berurutan), contohnya: tv dan film. Multimedia interaktif adalah suatu 
multimedia yang dilengkapi dengan alat pengontrol yang dapat dioperasikan oleh pengguna, sehingga pengguna dapat memilih apa yang dikehendaki untuk proses selanjutnya. Contoh multimedia interaktif adalah: multimedia pembelajaran interaktif, aplikasi game, serta game interaktif (Ariani, 2010).

Adapun pengertian multimedia interaktif adalah suatu multimedia yang dilengkapi dengan alat pengontrol yang dapat dioperasikan oleh pengguna, sehingga pengguna dapat memilih apa yang dikehendaki untuk proses selanjutnya. Contoh multimedia interaktif adalah pembelajaran interaktif, aplikasi game, dll (Ripai, 2015).

Salah satu komponen sistem pembelajaran, pemilihan dan penggunaan multimedia interaktif harus memperhatikan tiga karakteristik(Ripai, 2015:62-63), yaitu:

1. Memiliki lebih dari satu media konvergen, misalnya menggabungkan unsur audio dan visual.

2. Bersifat interaktif, dalam pengertian memiliki kemampuan untuk mengakomodasi respon pengguna.

3. Bersifat mandiri, dalam pengertian memberi kemudahan dan kelengkapan isi sedemikian rupa sehingga pengguna bisa menggunakan tanpa bimbingan orang lain

Ada beberapa manfaat teknologi multimedia dalam proses belajar mengajar (Munir, 2013:141) yaitu, membantu pendidik dalam menjelaskan suatu konsep yang sulit dijelaskan tanpa bantuan multimedia,membangkitkan motivasi belajar peserta didik,membuat presentasi pembelajaran menjadi lebih menarik, sangat efesien dalam segi waktu bagi pendidik

Multimedia pembelajaran (Munir, 2013:116) sebaiknya memenuhi fungsi sebagai berikut:

1. Mampu memperkuat respon pengguna secepatnya dan sesering mungkin.

2. Mampu memberikan kesempatan kepada peserta didik untuk mengontrol laju kecepatan belajarnya sendiri.

3. Memperhatikan bahwa peserta didik mengikuti suatu urutan yang koheren dan terkendalikan

4. Mampu memberikan kesempatan adanya partisi pengguna dalam bentuk respon, baik berupa jawaban, pemilihan, keputusan, percobaan dan lain-lain.

Ada enam kriteria dalam pemilihan media pembelajaran (Sudjana, 2013:5). Kriteriakriteria tersebut yaitu ketepatannya dengan tujuan pembelajaran,dukungan terhadap isi bahan pelajaran, kemudahan memperoleh media, keterampilan guru dalam menggunakannya, tersedia waktu untuk menggunakannya, sesuai dengan taraf berfikir siswa.

Berdasarkan uraian di atas, dapat disimpulkan bahwa multimedia interaktif adalah perpaduan antara berbagai media yang berupa teks, gambar, grafik, sound, animasi, video interaksi, dan lain-lain yang telah dikemas menjadi file digital dan memenuhi tiga kriteria, yaitu: memiliki lebih dari satu media konvergen, misalnya menggabungkan unsur audio dan visual; bersifat interaktif, dalam pengertian memiliki kemampuan untuk mengakomodasi respon pengguna; bersifat mandiri, dalam pengertian memberi kemudahan dan kelengkapan isi sedemikian rupa sehingga pengguna bisa menggunakan tanpa bimbingan orang lain

Sedangkan pengertian edutainment secara etimologi berasal dari kata education dan entertainment. Education berarti pendidikan, sedangkan entertainment berarti hiburan. Jadi, dari segi bahasa, edutainment adalah pendidikan yang menghibur atau menyenangkan. Sementara itu, dari segi terminologi, edutainment adalah suatu proses pembelajaran yang didesain sedemikian rupa, sehingga muatan pendidikan dan hiburan bisa dikombinasikan secara harmonis untuk menciptakan pembelajaran yang menyenangkan. Dalam hal ini, pembelajaran yang menyenangkan biasanya dilakukan dengan humor, permainan (game), bermain peran (role play), dan demonstrasi(Hamid, 2014)

Media edutainment merupakan salah satu media pembelajaran yang menarik dalam penampilan, menyenangkan dalam penyampaian, serta mudah dicerna karena siswa tidak hanya duduk diam mendengarkan, namun mereka diajak untuk ikut berpikir dan merespon apa yang disampaikan dan yang ditampilkan. Media edutainment adalah suatu alat 
komunikasi yang berisi informasi berupa grafik, fotografi, atau alat-alat untuk menyajikansuatu peristiwa yang bersifat mendidik digabungkan dengan hiburan secara harmonis agar pembelajaran berlangsung menarik dan menyenangkan (Permadi et al., 2013). Media pembelajaran berbasis edutainment menggabungkan prinsip education (pendidikan) dan entertainment yang pada umumnya memanfaatkan komputer sebagai media penyajiannya. Karena memuat unsur hiburan, media pembelajaran berbasis edutainment ini akan lebih disukai siswa dibandingkan dengan media pembelajaran biasa. Media pembelajaran yang membawa dan membangkitkan rasa senang bagi siswa itu dapat memperbaharui semangat belajar, membantu memantapkan pengetahuan pada benak para siswa.

Berdasarkan penjelasan mengenai multimedia interaktif berbasis edutainment di atas, maka dapat disimpulkan bahwa multimedia interaktif berbasis edutainment adalah multimedia interaktif yang menggabungkan prinsip education (pendidikan) dan entertainment yang pada umumnya memanfaatkan komputer sebagai media penyajiannya. Multimedia interaktif berbasis edutainment ini memiliki kualitas isi, intruksional dan tujuan yang jelas sehingga dapat memotivasi dan membantu pemahaman siswa serta dapat menghasilkan proses pembelajaran menjadi lebih efektif. Media pembelajaran berbasis edutainment ini akan lebih disukai siswa dibandingkan dengan media pembelajaran biasa, karena dalam multimedia interaktif berbasis edutainment ini memuat unsur hiburan, menyajikan informasi dalam bentuk yang menyenangkan, menarik, mudah dimengerti dan jelas. Informasi akan mudah dipahami karena semua panca indera, terutama telinga dan mata digunakan untuk menyerap informasi itu.

Multimedia interaktif berbasis edutainment ini dibuat dengan menggunakan aplikasi "Macromedia Flash Profesional 8" "Macromedia Flash Profesional 8" merupakan sebuah software multimedia milik macromedia (sekarang milik Adobe) dimana di dalamnya terdapat semua kelengkapan yang dibutuhkan, mulai dari fitur menggambar, ilustrasi, mewarnai, animasi dan programming (Indrawaty et al., 2012). Adapun salah satu dari tampilan multimedia interaktif berbasis edutainment tersebut adalah sebagai berikut:
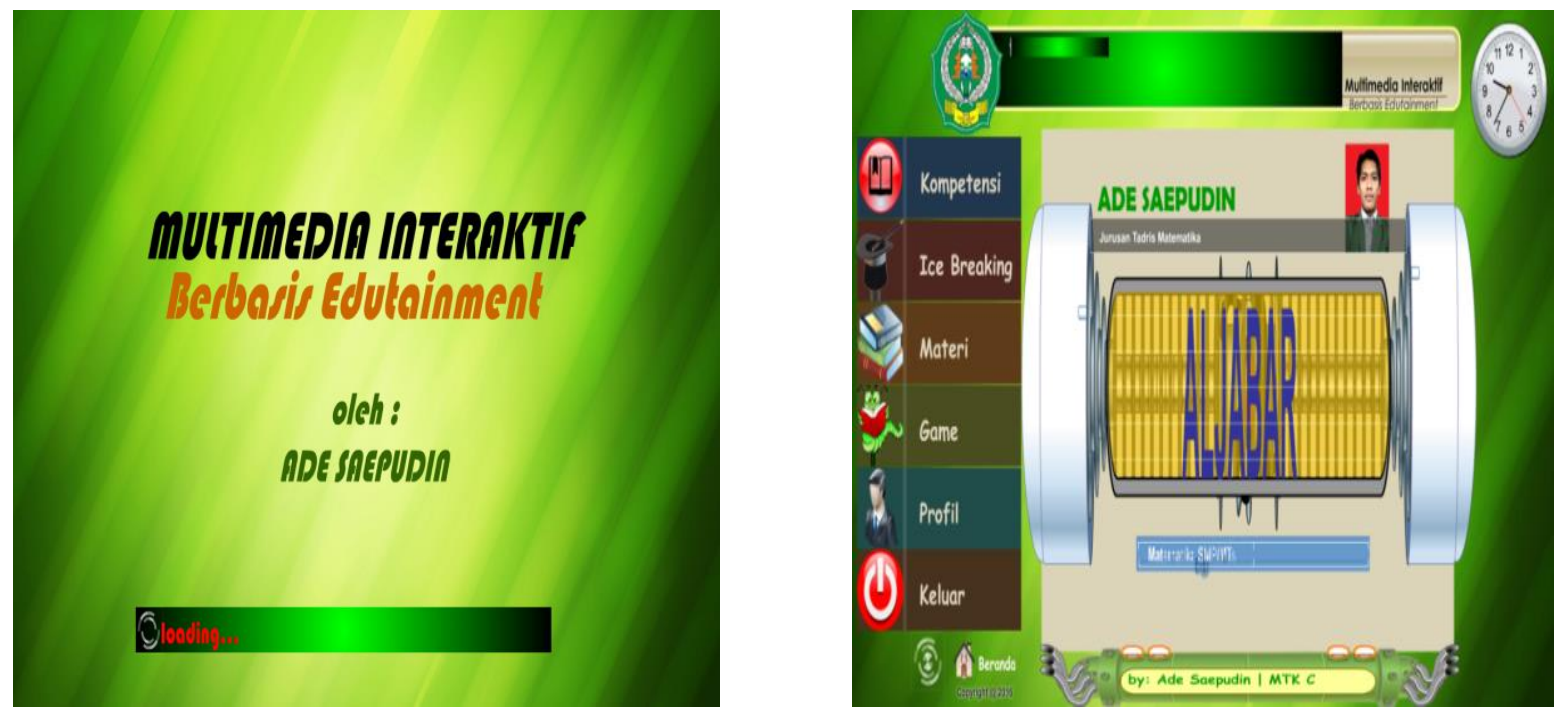

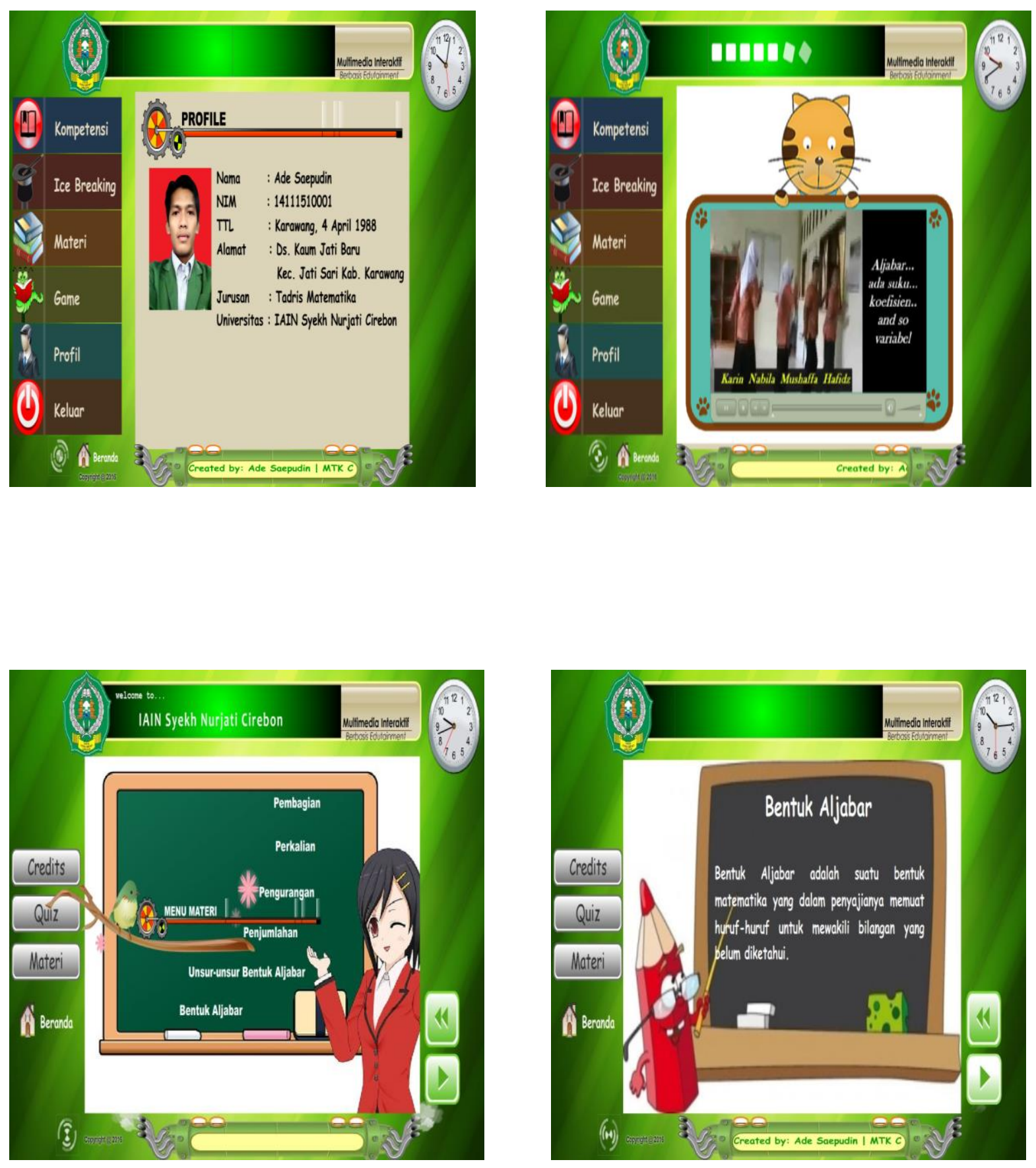

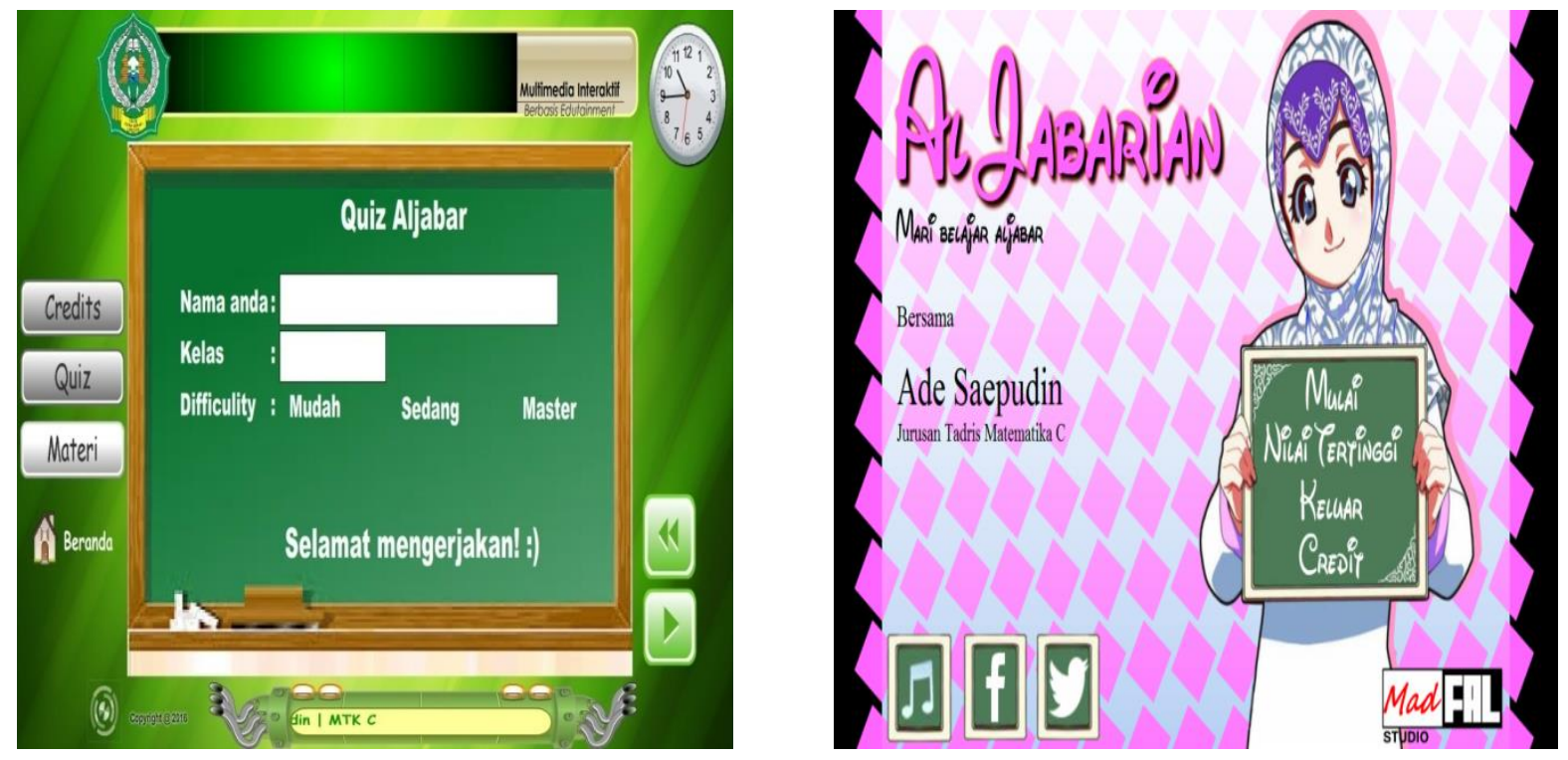

\section{b. Prestasi Belajar}

Prestasi belajar adalah sebuah kalimat yang terdiri dari dua kata, yaitu "prestasi" dan "belajar".Kata Prestasi berasal dari bahasa belanda yaitu prestatie yang dalam bahasa Indonesia menjadi kata prestasi yang berarti hasil usaha. Dalam dunia pendidikan prestasi belajar adalah suatu hal yang mutlak untuk dicapai. Hal itu karena tolak ukur sebuah proses belajar mengajar dapat dilihat dari prestasi yang dihasilkan siswa (Suyati, 2015:3). Prestasi belajar merupakan hal yang tidak dapat dipisahkan dari kegiatan belajar karena kegiatan belajar merupakan proses, sedangkan prestasi merupakan hasil dari proses belajar. Untuk memahami lebih jauh tentang pengertian prestasi belajar, peneliti akan menjabarkan makna dari kedua kata tersebut.

Dalam Kamus Besar Bahasa Indonesia yang dimaksud dengan prestasi adalah hasil yang telah dicapai dari yang telah dilakukan, dikerjakan dan sebagainya(Tim Penyusun Kamus 1999:787). Menurut Hamdani prestasi adalah hasil dari suatu kegiatan yang telah dikerjakan, diciptakan, baik secara individual maupun kelompok. Prestasi tidak akan pernah dihasilkan selama seseorang tidak melakukan kegiatan (Hamdani, 2011:137). Menurut Djamarahprestasi adalah sebagai hasil yang telah diciptakan, hasil pekerjaan, hasil yang menyenangkan hati yang diperoleh dengan jalan keuletankerja(Djamarah, 1994:20-21). Menurut Harahap dalam Hamdani memberikan batasan bahwa prestasi adalah penilaian pendidikan tentang perkembangan dan kemajuan siswa yang berkenaan dengan penguasaan bahan pelajaran yang disajikan kepada mereka serta nilai-nilai yang terdapat dalam kurikulum (Hamdani, 2011:138). Dari beberapa pengertian prestasi tersebut dapat disimpulkan bahwa prestasi adalah hasil dari suatu kegiatan seseorang atau kelompok yang telah dikerjakan, diciptakan dan menyenangkan hati yang diperoleh dengan jalan bekerja.

Sedangkan pengertian belajar adalah tahapan perubahan seluruh tingkah laku individu yang relatif menetap sebagai hasil pengalaman dan interaksi dengan lingkungan yang melibatkan proses kognitif (Syah, 2004:68). Menurut Hamdani belajar adalah perubahan tingkah laku atau penampilan, dengan serangkaian kegiatan. Misalnya, dengan membaca, mengamati, mendengarkan, meniru, dan sebagainya (Hamdani, 2011:21-22). Menurut Djamarah belajar adalah serangkaian kegiatan jiwa dan raga untuk memperoleh suatu tingkah laku sebagai hasil dari pengalaman individu dalam interaksidengan lingkungannya, yang menyangkut kognitif, afektif dan psikomotorik(Djamarah, 2011:141).Menurut Slametobelajar adalah suatu proses perubahan, yaitu perubahan tingkah laku sebagai hasil interaksi dalam lingkungannya dalam memenuhi kebutuhan hidupnya (Slameto, 2003:2). Menurut Morgan, sebagaimana dikutip Mustaqim mendefinisikan belajar sebagai berikut: "Learning is any relatively permanent change in behavior that is a result of past experience." Belajar adalah perubahan tingkah laku yang 
relatif tetap yang merupakan hasil pengalaman masa lalu (Mustaqim, 2001:33). Dari beberapa pengertian belajar tersebut dapat disimpulkan bahwa belajar adalah "suatu proses adaptasi atau penyesuaian tingkah laku yang berlangsung secara progresif dan menetap pada seseorang untuk memperoleh suatu perubahan yang baru yang dihasilkan dari proses latihan atau pengalaman individu itu sendiri dalam berinteraksi dengan lingkungannya".

Adapun pengertian prestasi belajar dalam Kamus Besar Bahasa Indonesiaadalah penguasaan pengetahuan atau keterampilan yang dikembangkan oleh mata pelajaran, lazimnya ditunjukan dengan nilai tes atau angka nilai yang diberikan oleh guru (Tim Penyusun Kamus, 1999:787). Prestasi belajar adalah hasil yang dicapai seseorang setelah mengikuti kegiatan belajar (Utomo, 2008:46). Menurut Hamdani prestasi belajar adalah tingkat kemanusiaan yang dimiliki siswa dalam menerima, menolak, dan menilai informasiinformasi yang diperoleh dalam proses belajar mengajar. Prestasi belajar seseorang sesuai dengan tingkat keberhasilan sesuatu dalam mempelajari materi pelajaran yang dinyatakan dalam bentuk nilai atau rapor setiap bidang studi setelah mengalami proses belajar mengajar (Hamdani, 2011:138-139). Menurut Basri prestasi belajar adalah hasil usaha belajar yang dicapai seorang siswa berupa suatu kecakapan dari kegiatan belajar bidang akademis disekolah pada jangka waktu tertentu yang dicatat pada setiap akhir semester dalam bukti laporan yang disebut rapor (Basri, 2015:154).

Berdasarkan penjelasan di atas, dapat disimpulkan bahwa prestasi belajar adalah hasil yang dicapai oleh siswa selama berlangsungnya proses belajar mengajar dalam jangka waktu tertentu, umumnya prestasi belajar dalam sekolah berbentuk pemberian nilai (angka) dari guru kepada siswa sebagai indikasi sejauh mana siswa telah menguasai materi pelajaran yang disampaikannya, biasanya prestasi belajar ini dinyatakan dengan angka, huruf, atau kalimat dan terdapat dalam periode tertentu 4):

Ditinjau dari fungsinya, fungsi prestasi belajarberfungsi sebagai berikut(Arifin, 1990:3-

1) Prestasi belajar sebagai indikator kualitas dan kuantitas pengetahuan yang telah dikuasai anak didik.

2) Prestasi belajar sebagai lambang pemuasan hasrat ingin tahu.

3) Prestasi belajar sebagai bahan informasi dalam inovasi pendidikan.

4) Prestasi belajar sebagai indikator intern dan ekstern dari suatu institusi pendidikan. Indikator intern adalah prestasi belajar dapat dijadikan indikator tingkat produktifitas suatu institusi pendidikan. Sedangkan indikator ekstern menunjukkan bahwa prestasi belajar dijadikan indikator kesuksesan anak didik di masyarakat.

5) Prestasi siswa dapat dijadikan indikator terhadap daya serap (kecerdasan) anak didik.

Sedangkan menurut Cronbach (1960) dikutip dalam buku "Evaluasi

Instruksional, Prinsip-Teknik-Prosedur" karangan Arifin kegunaan prestasi belajar di antaranya(Arifin, 1990:4):

a) Sebagai umpan balik bagi pendidik dalam mengajar.

b) Untuk keperluan diagnostik.

c) Untuk keperluan bimbingan dan penyuluhan.

d) Untuk keperluan seleksi.

e) Untuk keperluan penempatan atau penjurusan.

f) Untuk menentukan isi kurikulum.

g) Untuk menentukan kebijaksanaan sekolah.

Prestasi belajar siswa banyak dipengaruhi oleh berbagai faktor, baik berasal dari dalam diri siswa itu sendiri (internal) maupun dari luar (eksternal). Prestasi belajar yang dicapai oleh siswa pada hakikatnya merupakan hasil interaksi dari berbagai faktor tersebut. Oleh karena itu, pengenalan guru terhadap faktor yang mempengaruhi prestasi belajar siswa sangat penting artinya dalam rangka membantu siswa dalam mencapai prestasi belajar yang seoptimal mungkin sesuai dengan kemampuannya masing-masing. Adapun faktorfaktor yang dimaksud adalah sebagai berikut (Setiawati, 1993):

3) Faktor yang berasal dari diri sendiri (Internal)

(a) Faktor jasmaniah (fisiologi), yang termasuk faktor ini adalah panca indera yang tidak berfungsi sebagaimana mestinya, seperti mengalami sakit, cacat tubuh atau perkembangan yang tidak sempurna, berfungsinya kelenjar tubuh yang membawa kelainan tingkah laku. 
(b) Faktor psikologis terdiri atas:

i. Faktor intelektif yang meliputi faktor potensial yaitu kecerdasan dan bakat serta kecakapan nyata (prestasi yang dimiliki),

ii. Faktor nonintelektif, yaitu unsur-unsur kepribadian seperti sikap, kebiasaan, minat, kebutuhan, motivasi, emosi, dan penyesuaian diri,

iii. Faktor kematangan fisik maupun psikis.

(c) Faktor yang berasal dari luar diri (Eksternal)

(a) Faktor sosial yang terdiri atas:

i. Lingkungan keluarga,

ii. Lingkungan sekolah,

iii. Lingkungan masyarakat, dan

iv. Lingkungan kelompok

(b) Faktor budaya, seperti adat istiadat, ilmu pengetahuan, teknologi, dan kesenian.

(c) Faktor lingkungan fisik, seperti fasilitas rumah dan fasilitas belajar.

1. Indikator Prestasi Belajar

Pada prinsipnya, pengungkapan hasil belajar ideal meliputi segenap ranah psikologis yang berubah sebagai akibat pengalaman dan proses belajar siswa. Namun demikian, pengungkapan perubahan tingkah laku seluruh ranah, khususnya ranah rasa, murid sangat sulit.Hal ini disebabkan perubahan hasil belajar itu ada yang bersifat intangible (tak dapat diraba). Oleh karena itu, yang dapat dilakukan guru dalam hal ini adalah hanya mengambil cuplikan perubahan tingkah laku yang dianggap penting dan diharapkan dapat mencerminkan perubahan yang terjadi sebagai hasil belajar siswa, baik yang berdimensi cipta, rasa ataupun yang berdimensi karsa. Kunci pokok untuk memperoleh ukuran dan data hasil belajar siswa adalah mengetahui garis-garis besar indikator (penunjuk adanya prestasi tertentu) yang dikaitkan dengan jenis prestasi yang hendak diukur (Syah, 2004:213-214). Berikut tiga macam indikator prestasi belajar :

a. Kognitif: pengetahuan, pemahaman, pengertian, aplikasi, analisis, sintesis dan evaluasi.Instrumen: pemberian tugas dan tes

b. Afektif: penerimaan, jawaban, penilaian, organisasi dan internalisasi. Instrumen: ketepatan waktu, jawaban penyelesaian tugas dan uji kompetensi serta hasil angket respon

b. Psikomotorik: kemampuan perceptual, ketepatan, gerakan keterampilan kompleks, gerakan ekspresif dan interpretative.Instrumen: pengamatan selama proses pembelajran.

Adapun yang akan diukur peneiliti dalam penelitian ini sebagaimana yang telah disebutkan dalam batasan masalah dalam bab 1 (satu) adalah hanya aspek kognitifnya saja.

\section{METODOLOGI}

\section{a. Populasi dan Sampel}

Populasi target dalam penelitian ini adalah seluruh siswa MTs. KHAS KempekCirebon, sedangkan populasi terjangkaunya adalah seluruh siswa kelas VIIMTs. KHAS Kempek-Cirebon semester genap tahun ajaran 2015/2016 yang berjumlah 402 siswa. Adapun sampel dalam penelitian ini adalah kelas VII E (kelas kontrol) berjumlah 46 siswa dan VII C (kelas eksperimen) berjumlah 47 siswa. Di sekolah MTs. KHAS Kempek antara siswa laki-laki dan perempuan tidak berada dalam satu kelas dalam artian siswa laki-laki dan perempuan dipisah. Untuk siswa laki-laki yaitu mulai dari kelas VII A sampai VII E dan perempuan mulai dari kelas VII F sampai VII G. Untuk lebih jelasnya populasi penelitian dapat dilihat pada tabel berikut:

Tabel 1. Populasi Siswa

\begin{tabular}{|c|c|c|c|l|c|}
\hline NO & Kelas & Jumlah Siswa & NO & Kelas & Jumlah Siswa \\
\hline 1 & VII A & 49 & 6 & VII F & 31 \\
\hline
\end{tabular}




\begin{tabular}{|c|c|c|c|l|c|}
\hline NO & Kelas & Jumlah Siswa & NO & Kelas & Jumlah Siswa \\
\cline { 1 - 5 } 2 & VII B & 48 & 7 & VII G & 33 \\
\hline 3 & VII C & 47 & 8 & VII H & 35 \\
\hline 4 & VII D & 42 & 9 & VII I & 35 \\
\hline 5 & VII E & 46 & 10 & VII J & 36 \\
\hline \multicolumn{5}{|c|}{ Total } \\
\cline { 1 - 3 }
\end{tabular}

\section{b. Desain Penelitian}

Penelitian ini menggunakan pendekatan kuantitatif dengan metode eksperimen dengan jenis control group pretes postes (Sugiyono, 2014). Pada pelaksanaannya, diberikan tes pretes untuk mengetahui kemampuan awal ranah kognitif setelah itu dilakukan proses belajar dengan menggunkan multimedia interaktif berbasis edutainment untuk kelas eksperimen kemudian diberikan postes untuk mengetahui prestasi belajar ranah kognitif siswa dan diberikan angket respon penggunaan multimedia interaktif berbasis edutainment. Adapun untuk kelas kontrol dilakukan proses pembelajaran konvensional tanpa menggunakan multimedia interaktif berbasis edutainment kemudian diberikan postes untuk mengetahui peningkatan prestasi belajar ranah kognitif siswa.

\section{c. Alur Pengolahan Data}

Instrumen dibuat sesuai dengan indikator pada kisi-kisi yang telah dibuat. Setelah instrumen tersebut terbentuk kemudian instrumen tersebut diuji ke validitasannya dengan dua cara yaitu validitas konstruk (expert judgment) dan validitas empirik. Setelah instrumen valid maka selanjutnya instrumen di uji kereliabilitas, di uji daya beda dan tingkat kesukarannya dengan menggunakan bantuan aplikasi excel dan menggunakan bantuan software SPSS 21.00. Setelah penelitian telah selesai dilaksanakan peneliti memperoleh hasil penelitian, langkah selanjutnya adalah uji persyaratan analisis. Cara yang digunakan dengan uji normalitas dan uji homogenitas. Maka selanjutnya akan dilakukan pengujian hipotesis dengan menggunakan persamaan regresi sederhana pada taraf signifikan $\propto=0,05$ dengan menggunakan bantuan software SPSS 21.00

\section{HASIL DAN PEMBAHASAN}

\section{a. Deskripsi Hasil Tes}

Setelah peneliti melakukan penelitian di MTs. KHAS Kempek-Cirebon, berdasarkan analisis data diperoleh respon siswa terhadap penggunaan multimedia interaktif berbasis edutainment dikatakan sangat kuat. Analisis data respon siswa terhadap penggunaan multimedia interaktif berbasis edutainment menunjukan bahwa untuk indikator kualitas isi dan tujuan penggunaan multimedia interaktif berbasis edutainment memiliki presentase 84,6\% dengan kategori sangat tinggi, untuk indikator kualitas intruksional memiliki presentase $73,1 \%$ dengan kategori tinggi, untuk indikator membantu pemahaman materi memiliki presentase $83,5 \%$ dengan kategori sangat baik, untuk indikator memotivasi siswamemiliki presentase $83,8 \%$ dengan kategori sangat tinggi, dan untuk indikator efektivitas penggunaan multimedia interaktif berbasis edutainment dalam pembelajaran matematika memiliki presentase $86,1 \%$ dengan kategori sangat tinggi. Rata-rata presentase dari semua indikator respon siswa terhadap penggunaan multimedia interaktif berbasis edutainment adalah $82,22 \%$ dan termasuk kedalam kategori sangat tinggi. Sehingga dapat disimpulkan bahwarespon siswa terhadap penggunaan multimedia interaktif berbasis edutainment adalah sangat baik.

Untuk mengetahui perbedaaan prestasi belajar siswa pada siswa yang menggunakan multimedia interaktif berbasis edutainment (kelas eksperimen) dan yang tidak menggunakan multimedia interaktif berbasis edutainment (kelas kontrol) dalam 
pembelajaran matematika di kelas VII MTs. Kyai Haji 'Aqiel Siradj (KHAS) Kempek Desa Pegagan Kecamatan Palimanan Kabupaten Cirebon, perlu diketahui beberapa nilai gain yang diperoleh siswa kelas eksperimen dengan kelas kontrol. Dalam penelitian ini dilakukan dua kali tes dengan soal yang sama, yaitu pretest dan posttest. Dari data pretes dan postes tersebut diambil nilai gain utuk mengetahui peningkatan prestasi belajar antara kedua kelas tersebut. Berdasarkan hasil output SPSS terdapat perbedaan peningkatan prestasi belajar siswa pada kelas eksperimen yang menggunakan multimedia interaktif berbasis edutainment dengan kelas kontrol yang tidak menggunakan multimedia interaktif berbasis edutainment. Hal tersebut ditunjukkan dengan nilai rata-rata posttest kelas eksperimen lebih tinggi dari pada nilai posttest kelas kontrol, nilai rata-rata pada kelas eksperimen adalah 48,75 sedangkan nilai rata-rata pada kelas kontrol adalah 34,04.

\section{b. Analisis Data}

\section{Uji Normalitas}

Uji normalitas dilakukan untuk mengetahui normal tidaknya suatu distribusi data. Kriteria pengambilan keputusan dalam uji normalitas adalah sebagai berikut:

a) Jika nilai signifikansi/P-value/Sig $\leq 0,05$ artinya data tidak normal.

b) Jika nilai signifikansi/P-value/Sig $\geq 0,05$ artinya data normal.

Dalam penelitian ini uji normalitas peneliti menggunakan software SPSS 21.00 maka diperoleh output data sebagai berikut :

\section{Tabel 2. UjiNormalitas}

Tests of Normality

\begin{tabular}{|r|r|r|r|r|r|r|r|}
\hline & uji hipotesis & \multicolumn{2}{|c|}{ Kolmogorov-Smirnova } & \multicolumn{3}{|c|}{ Shapiro-Wilk } \\
\cline { 3 - 8 } & & Statistic & \multicolumn{1}{c|}{ Df } & Sig. & Statistic & df & \multicolumn{1}{c|}{ Sig. } \\
\hline & $\begin{array}{l}\text { gain kelas } \\
\text { eksperimen } \\
\text { data } \\
\text { penelitian }\end{array}$ & .136 & 47 & .029 & .949 & 47 & .038 \\
& gain kelas control & .154 & 46 & .008 & .938 & 46 & .016 \\
\hline
\end{tabular}

a. Lilliefors Significance Correction

Berdasarkan hasil uji normalitas dengan SPSS 21.00 diperoleh nilai Sig. Gain siswa kelas eksperimen dengan uji-kolmogorof smirnov diperoleh (sig. 0,029) dan Sig. Gain siswa kelas kontrol diperoleh $(0,008)$.Karena nilai signifikansi dari kedua kelas tersebut lebih kecil dari $\alpha=0,05$, maka dapat disimpulkan bahwa data pada kelas eksperimen dan kelas kontrol tersebut berdistribusi tidak normal. Dengansebab data tersebut tidak normal maka tidak perlu menguji homogenitas, karena hasilnya tidak akan homogen.

Karena data gain kelas kelas eksperimen dan kelas kontrol berdistribusi tidak normal, dan merupakan pengujian pengaruh suatu perlakuan terhadap dua kelompok, dimana kelompok pertama merupakan kelompok kelas eksperimen dan yang kedua merupakan kelompok kelas kontrol, maka untuk pengujian hipotesisnya menggunakan statistik non-parametris (non-parametric statistic).Statistik non-parametris (Kadir, 2015:459)merupakan pengujian hipotesis dengan teknik analisis yang tidak mensyaratkan data berdistribusi normal atau bebas distribusi.Dengan sebab itu, sehingga dalam pengujian SPSS menggunakan Uji Mann Whitney untuk menentukan perbedaan dari dua variable tersebut. Berikut ini adalah hasil analisisnya: 
Tabel 4.25 NPar Tests

Mann-Whitney Test

Test Statistics ${ }^{a}$

\begin{tabular}{|l|l|}
\hline & data penelitian \\
\hline Mann-Whitney U & 628.500 \\
Wilcoxon W & 1709.500 \\
Z & -3.494 \\
Asymp. Sig. (2-tailed) & .000 \\
\hline
\end{tabular}

a. Grouping Variable: uji hipotesis

\section{Hipotesis:}

Ho = tidak terdapat perbedaaan peningkatan prestasi belajar yang signifikan antara kelas eksperimen dengan kelas kontrol.

$\mathrm{Ha}=$ terdapat perbedaaan peningkatan prestasi belajar yang signifikan antara kelas eksperimen dengan kelas kontrol.

\section{Kriteria pengujian:}

Jika nilai probabilitas atau nilai asymtop signifikansi (Asymp.Sig.)> 0,05 maka Ho diterima.

Jika nilai probabilitas atau nilai asymtop signifikansi (Asymp.Sig.) $<0,05$ maka Ho ditolak.

Berdasarkan tabel independent sample test diketahui bahwa diperoleh nilai Asymtop signifikansi (Asymp.Sig.) adalah 0,000. Kalau dibandingkan, maka nilainya akan lebih kecil dari $0,05(0,000<0,05)$, hal ini berarti bahwa Ho ditolak yang menunjukkan bahwa terdapat perbedaaan peningkatan prestasi belajar yang signifikan antara kelas eksperimen dengan kelas kontrol.

Perbedaan ini dapat dilihat dari perbedaan rata-rata (mean) Gain, dimana Gain kelas eksperimen didapatkan nilai rata-rata sebesar 48,75, sedangkan pada Gain kelas kontrol dipadatkan nilai rata-rata sebesar 34,04, sehingga selisihnya adalah 14,71. Hal ini berarti kelas eksperimen lebih baik dibandingkan kelas kontrol dalam meningkatkan prestasi belajar.

Selanjutnya untuk mengetahui prediksi seberapa besar nilai variabel dependen mempengaruhi variabel independen dilakukan persamaan regresi. Dalam penelitian ini peneliti menggunakan softwareSPSS 21.00 maka diperoleh output data sebagai berikut:

Tabel 4. Uji-t

Coefficients $^{\mathrm{a}}$

\begin{tabular}{|c|c|c|c|c|c|c|}
\hline \multirow{2}{*}{\multicolumn{2}{|c|}{ Model }} & \multicolumn{2}{|c|}{$\begin{array}{l}\text { Unstandardized } \\
\text { Coefficients }\end{array}$} & $\begin{array}{l}\text { Standardized } \\
\text { Coefficients }\end{array}$ & \multirow[t]{2}{*}{$\mathrm{T}$} & \multirow[t]{2}{*}{$\mathrm{Sig}$} \\
\hline & & $\mathrm{B}$ & Std. Error & Beta & & \\
\hline & (Constant) & -114.714 & 19.859 & & -5.776 & .000 \\
\hline 1 & $\begin{array}{l}\text { Multimedia interaktif } \\
\text { berbasis edutainment }\end{array}$ & 1.561 & .189 & .777 & 8.273 & .000 \\
\hline
\end{tabular}

a. Dependet Variable: peningkatanprestasi belajar siswa

Pada tabel ini menunjukkan regresi yang dicari. Nilai sig diatas adalah $0,000(<$ 0,05 ) dan didapat nilai uji $\mathrm{t}$ dengan $\mathrm{t}$ hitung $=8,273$ dengan derajat kebebasan $=\mathrm{n}-2=$ $47-2=45$ sehingga $t$ tabel sebesar 1,68 . Karena nilai sig $0,000<0,05$ atau tabel $(1,68)<$ thitung $(8,273)$, maka dapat disimpulkan bahwa nilai pada kolom B adalah signifikan artinya persamaan yang paling tepat untuk kedua variabel tersebut adalah :

$\mathrm{Y}=\mathrm{a}+\mathrm{bX}$

$\mathrm{Y}=-114,714+1,561 \mathrm{X}$

Dengan $\mathrm{X}=$ Multimedia interaktif berbasis edutainment

$\mathrm{Y}=$ PeningkatanPrestasi belajar siswa

Prestasi belajar siswa $=-114,714+1,561$ Multimedia interaktif berbasis edutainment 


\section{Interpretasinya yaitu:}

- Konstanta $\mathbf{a}=-114,714$

Artinya jika multimedia interaktif berbasis edutainment nilainya adalah 0 , maka prestasi belajar siswa nilainya sebesar -114,714.

- Koefesien $\mathbf{b}=1,561$

Artinya jika multimedia interaktif berbasis edutainment ditingkatkan 1 satuan, maka prestasi belajar siswa akan meningkat sebesar 1,561 satuan.

Berdasarkan pengujian diatas, variabel multimedia interaktif berbasis edutainment memiliki nilai $p$-Value (pada kolom sig.) 0,000. Dan 0,000 <Level of significant 0,05 , dan tabel $(1,68)<$ thitung $(8,273)$ artinya signifikan. Signifikan disini berarti Ha diterima dan Ho ditolak, artinya adanya pengaruh penggunaan multimedia interaktif berbasis edutainment pada pembelajaran matematika terhadap peningkatan prestasi belajar siswa.

\section{KESIMPULAN DAN SARAN}

\section{a. Kesimpulan}

Berdasarkan hasil penelitian dan pembahasan, maka dapat disimpulkan sebagai berikut:

1. Berdasarkan pengolahan data hasil angket siswa memberikan respon yang positif terhadap peggunaan multimedia interaktif berbasis edutainment. Hal ini terbukti dengan banyaknya jawaban siswa yang merespo psitif dan siswa yang menuawab sangat setuju maupun setuju dari seluruh pernyataan yang terdapat pada angket. Keseluruhan pernyataan dari kelima indikator, yang sebagian besar responden $(82,22 \%)$ menyatakan sangat setuju ataupun setuju, dan sisanya sebagian kecil $(17,78)$ siswa menyatakan ragu-ragu, tidak setuju dan bahkan menyatakan sangat tidak setuju. Berdasarkan interpretasi skor angket bahwa respon siswa dalam kategori sangat kuat (Sangat baik). Sehingga dapat disimpulkan bahwa penggunaan multimedia interaktif berbasis edutainment memiliki efek yang sangat kuat (Sangat baik) terhadap peningkatan prestasi belajar matematika siswa.

2. Terdapat perbedaan peningkatan prestasi belajar siswa pada kelas eksperimen yang menggunakan multimedia interaktif berbasis edutainment dengan kelas kontrol yang tidak menggunakan multimedia interaktif berbasis edutainment. Hal tersebut ditunjukkan dengan nilai rata-rata posttest kelas eksperimen lebih tinggi dari pada nilai posttest kelas kontrol, nilai rata-rata pada kelas eksperimen adalah 48,75 sedangkan nilai rata-rata pada kelas kontrol adalah 34,04.

3. Berdasarkan hasil pengujian regresi menggunakan bantuan SPSS 21.00 diperoleh koefisien korelasi $(\mathrm{r})=0,777$ yang termasuk dalam kategori kuat dan koefisien determinasi $\left(\mathrm{r}^{2}\right)=0,603$ atau $603 \%$. Adapun persamaan regresinya adalah $Y=$ $-114,714+1,561 X$. Persamaan ini memiliki koefisien arah regresi linier (b) $=1,561$ bertanda positif artinya respon siswa naik satu satuan, maka prestasi siswa dalam pembelajaran matematika akan meningkat 1,561 kali. Hasil uji statistik menunjukkan bahwa thitung $>$ tabel $=8,273>1,68$. Hal ini berarti terdapat pengaruh yang signifikan penggunaan multimedia interaktif berbasis edutainment pada pembelajaran matematika pokok bahasan operasi hitung bentuk aljabar terhadap peningkatan prestasi belajar siswa. Besarnya pengaruh penggunaan multimedia interaktif berbasis edutainment terhadap prestasi belajar matematika siswa adalah $60,3 \%$ dan sisanya dipengaruhi oleh faktor lain.

\section{b. Saran}

Berdasarkan hasil temuan dan pembahasan pada penelitian yang telah dilaksanakan, ada beberapa saran yang ingin penulis sampaikan, yaitu:

1. Bagi guru diharapkan mampu menggunakan multimedia interaktif berbasis edutainment ini sebagai modal inovasi dan kreativitas dalam pembelajaran matematika untuk meningkatkan prestasi belajar matematika siswa, karena penggunaannya sangat mudah dan sesuai era sekarang.

2. Bagi siswa diharapkan lebih banyak berperan aktif, mempunyai tanggung jawab belajar sebagai siswa dan berusaha menyukai pelajaran matematika, karena dengan 
kita suka maka secara perlahan kita mengerti pelajaran matematika sehingga dapat meningkatkan prestasi belajar matematika secara tidak langsung.

3. Bagi orang tua diharapkan senantiasa memberikan bimbingan dan dorongan yang intensif dalam belajar sehingga siswa dapat meningkatkan prestasi belajarnya, akan tetapi hindari hal-hal yang justu menekan siswa.

4. Perlu dilakukan penelitian lanjutan, karna penelitian yang telah dilakukan memiliki beberpa keterbatasan pada variabel penelitan yaitu penggunaan multimedia interaktif berbasis edutainment sebagai varabel $\mathrm{X}$ dan peningkatan prestasi belajar matematika sebagai variabel Y, populasi penelitian siswa kelas VII, sampel VII C sebagai kelas eksperimen dan VII E sebagai kelas kontrol, pokok bahasan operasi hitung bentuk aljabar. Penelitian yang telah dilakukan mengenai pengaruh penggunaan multimedia interaktif berbasis edutainment terhadap peningkatan prestasi belajar matematika siswa, oleh karena itu diharapkan untuk penelitian selanjutnaya lebih memperluas variabel penelitian, pokok bahasan, populasi dan sampel penelitian.

\section{DAFTAR PUSTAKA}

Ariani, N. dan D.H., 2010. Pembelajaran Multimedia di Sekolah, Jakarta: Prestasi Pustakarya.

Arifin, Z., 1990. Evaluasi Intruksional, Prinsip-Teknik-Prosedur, Bandung: Remaja Rosdakarya.

Djamarah, S.B., 1994. Prestasi Belajar dan Kompetensi Guru, Surabaya: Usaha Nasional.

Hamdani, 2011. STRATEGI BELAJAR MENGAJAR 10th ed., Bandung: CV Pustaka Pelajar.

Hamid, M.S., 2014. Metode Edutainment, Jogjakrata: DIVA Press.

Indrawaty, Y., Rosmala, D. \& Ramadhani, 2012. Implementasi Model Multimedia Interaktif Skenario Timeline Tree pada Simulasi Ibadah Wajib dalam Agama Islam. Jurusan Teknik Informatika Institut Teknologi Nasional Bandung, 3(3), pp.1-8.

Mustaqim, 2001. Psikologi Pendidikan, Yogyakarta: Pustka Pelajar Offset.

Ningsih, D.S., 2014. Meningkatkan Prestasi Belajar Matematika Melalui Pembelajaran

Kooperatif Tipe JIGSAW Pada Siswa SMK Negeri 3 Meulaboh Tahun Ajaran 2013/2014.

Jurnal Pendidikan Matematika, 1(1), pp.67-84.

Permadi, S., Kuswadi \& Daryanto, J., 2013. Peningkatan Pemahaman Konsep Dampak Pengambilan Bahan Alam Melalui Media Edutainment Pada Pembelajaran IPA. Jurnal PGSD FKIP Universitas Sebelas Maret.

Ripai, A., 2015. MEDIA PEMBELAJARAN Teori dan Praktik, Cirebon: IAIN SNJ.

Rohmawati, S., 2009. Penerapan Metode Edutainment untuk Meningkatkan Respon Siswa dalam Pembelajaran Matematika. Universitas Muhamadiyah Surakarta.

Setiawati, U. dan, 1993. Belajar Mengajar, Bandung: Remaja Rosdakarya.

Sugiyono, 2014. Metode Penelitian Kuantitatif, Kualitatif, dan R\&D 21st ed., Bandung: Alfabeta.

Suyati, 2015. Peningkatan Prestasi Belajar Siswa dalam Mata Pelajaran Matematika Operasi Hitung Perkalian dengan Metode Bermain Kartu. , 2(November).

Syah, M., 2004. Psikologi Belajar, Jakarta: Raja Grafindo Persada.

Tanrere, M. \& Side, S., 2012. The Development Of Chemo-Edutainment Media Through 
Macromedia Flash MX Software for Chemistry Science Intruction at Junior Secondary School. Jurusan Kimia FMIPA UNM Makassar, 18(November 2011), pp.156-162.

Tim Penyusun Kamus, P.P. dan P.B., 1999. Kamus Besar Bahasa Indonesia, Jakarta: Balai Pustaka.

Munir, 2013. MULTIMEDIA Konsep \& Aplikasi dalam Pendidikan 2nd ed. R. dan Nurfitriansyah, ed., Bandung: Alfabeta. 